\title{
The Impact of Transparency on the Citizen Participation in Decision- Making at the Municipal Level in Romania
}

\author{
Bianca Radu \\ Babeș-Bolyai University, Faculty of Political, Administrative and Communication \\ Sciences, Romania \\ bianca.radu@fspac.ro \\ https://orcid.org/0000-0003-1766-6055
}

Received: 9. 10. 2018

Accepted: 12. 2. 2019

\section{ABSTRACT}

The article analyses the implementation of the transparency law and investigates whether its adoption generated more citizens' participation in the decision making process at municipal level in Romania. The research consisted of an analysis of the transparency reports that municipal authorities need to compile every year. We analysed the reports compiled by 28 cities and 5 sectors of the Bucharest municipality for the years 2014, 2015, 2016 and 2017. Additional information about the challenges of the implementation of the law was collected from previous studies conducted by nongovernmental organizations on this topic. The research showed that public institutions increased the transparency of the decision making process by disclosing draft normative proposals and the documents the proposals were based on. The level of citizens' participation in the consultation and deliberation stages of the decision making process remained low over the period analysed, even though a small increase could be observed. The number of recommendations received on draft normative acts was low. The research showed that citizens' suggestions had higher chances to be included in final decisions if they were voiced during Local Council meetings. Besides providing empirical insights in the implementation of the transparency law in Romania, the article provides the researchers with evidence that increased decisional transparency does not automatically lead to greater citizens' involvement in the decision making process.

Keywords: transparency, citizens' participation, decision making, public administration reform, Romanian municipalities

$J E L: K 23$ 


\section{Introduction}

The importance of governmental transparency and access to public information has risen on the public agenda as the citizens' trust in public institutions decreased. Within the context of New Public Management reforms, the position of citizen in the relationship with public institutions changed from being a customer to being a partner (Lee and Kwak, 2012). Transparency is a desired principle of good governance and an instrument for reducing corruption, and increasing trust in government and accountability of public officials (Grimmelikhuijsen, 2009; Meijer, 2009). Even though its benefits are much praised, they are rather overrated (Porumbescu et al., 2017) and difficult to achieve.

The process of reaching greater transparency in government was strenuous for countries in Central and Eastern Europe, which had to deal with the legacy of the communist regime (Asllani, 2016; Kovač, 2016). In Romania, during communism transparency of the decision making process was neither desired nor encouraged, and the decisions were made internally by the communist elite and then communicated on the public agenda. Even though the party propaganda proclaimed that the decisions were representative of the working class opinions and the laws were passed with almost unanimous votes, people did not have any saying in the final decision. Any opposition or contestation of the formal decisions were discouraged and harshly punished by Securitate (the Romanian secret police of the Romanian Communist Party), therefore public institutions became opaque and closed to any communication with the public. Citizens were "administered" beneficiaries of public services rather than partners, and they had a reduced trust in the capacity of government to solve their problems (Hințea and Țiclău, 2017). The mistrust in public institutions preserved after the fall of communist regime in 1989. The reform of public administration lacked coherence, and it was driven rather by external factors (such as accession to the European Union) than by internal ideological beliefs (Hințea and Țiclău, 2017). Frequent changes of legislation and of the politically appointed officials made the implementation of administrative reforms difficult and unsustainable on long term (Radu, 2015).

More than ten years after the fall of communism regime had passed until the legislation regarding transparency in the decision making process was adopted in Romania. The main driving force was the pressure of the accession to the European Union. In terms of achieving greater transparency, a more important concern of the political class was to open archives and secret police records (Dragoș, 2006, p. 26) rather than to increase the amount of public information disclosed to citizens. The law on decisional transparency passed in 2003 is among a set of regulations adopted at the beginning of 2000s that aimed to increase openness of public institutions, such as free access to public information (2001), transparency in public office, in commercial transactions and in debts of the state (2003), and public's access to environmental information (2005). Civil society was involved in drafting the two pieces of legislation regarding access to information and decisional transparency, and their adoption was an important milestone toward building a more predictable and 
open government. However, both the disclosure of information and making the decision making process more transparent were goals difficult to achieve as Romanian public institutions lacked administrative capacity and true commitment toward reaching them (Schnell, 2018; Radu and Dragoș, 2019).

The article aims to analyze the law on decisional transparency, and whether its adoption generated more citizens' participation in the legislative process. The scope of the research aims to cover a gap of information that exists about the citizens' participation in the formal decision making process. Even though there are other academic researches about the free access to public information and transparency of public institutions conducted in Romania, none of them looks at the degree of citizens' participation in different stages of the decision process at municipal level.

In the following section we will define and conceptualize transparency in the public sector and the benefits of increasing transparency of public institutions. Then, the analysis will focus on presenting the main legal requirements of the Romanian law on decisional transparency, followed by a statistical analysis of the annual reports regarding the application of the law between 2014 and 2017. The article will conclude on the impact of the law and will attempt to explain causes of the low level of citizens' participation in the decision making process.

\section{Conceptualizing governmental transparency and benefits of citizens' participation in the decision making process}

Transparency of public institutions means to provide information to the public in order to achieve several objectives: to facilitate greater understanding of what public organizations do, who gains and who loses, to encourage citizens' participation and involvement in public affairs, to monitor the activity and performance of government, and to predict how governmental decisions will impact people and the environment. Transparency is a normative concept that sets standards for the evaluation of public actors (Meijer, 2013). Transparency along openness are complementary ethical principles of good administration (Kovač, 2016) that support other principles of law, instead of having a self-standing meaning (Prechal and Leeuw, 2007, p. 52).

Transparency of public institutions is a much praised remedy for many issues of public administration. Researchers argue that transparency lowers corruption, increases government financial performance and accountability, makes more accessible the activity of public institutions and reduces the risk of arbitrary action (Grimmelikhuijsen, 2009; Garrido-Rodriguez et al., 2017; Kim and Lee, 2012; Asllani, 2016). However, there are studies that show mix results for the core of transparency goals such as trust, legitimacy and accountability (Cucciniello et al., 2017; Grimmelikhuijsen, 2012), which suggests that the benefits are not clear-cut and other contextual and human factors influence the effect of transparency. 
Researchers have highlighted that increasing organizational transparency might have several drawbacks. Grimmelikhuijsen (2009) and Curtin and Meijer (2006) argued that increased transparency might lower trust in government because it might expose its unlawful activity that can be criticized. According to O'Neil apud Porumbescu et al. (2017), transparency could conduct to information overload, generate confusion and therefore uncertainty. Garrido-Rodriguez et al. (2017) pointed that greater governmental transparency might reduce its legitimacy. Few citizens might access public information, as the nongovernmental organizations or the journalists might be the main beneficiaries of governmental transparency, and this triggers debates about their representativeness (Curtin and Meijer, 2006). Hood (2007) showed that when the demand for greater transparency meets bureaucrats' blame avoidance, side-effects or reverse-effects might occur.

The simple disclosure of legally required public information is not a sufficient condition for reaching higher transparency. Publishing a great deal of information does not mean being more transparent (Grimmelikhuijsen, 2012), because the disclosed information should be accessible and relevant for citizens (Cucciniello and Nasi, 2014; Park and Blenkinsopp, 2017; Heimstädt and Dobusch, 2018), meaning that the information should be "complete, verifiable, accurate, balanced, comparable, clear, timely, and reliable" (Rawlins apud Park and Blenkinsopp, 2017). In addition, citizens should be able to understand the information disclosed (Porumbescu et al., 2017), therefore it is equally important how the information is presented to the public. Prechal and Leeuw (2007) highlight that public institutions should have clear procedures for disclosing public information, as well as clear and predictable channels for collecting information from citizens.

Transparency can be proactive or reactive (Ben-Aaron et al., 2017) depending on the incentive to disclose public information. Proactive transparency refers to public information disclosed voluntarily in the absence of a request for information, while reactive transparency refers to information that is made available in response to a request. Disclosure of information can be made in real-time or retrospective (Grimmelikhuijsen, 2012; Hood, 2007). Real-time transparency is characterized by continuous disclosure of information as soon as it is created; however, some public information is suitable only for retrospective reporting (such as in the case of project performance or in the case of minutes of public meetings).

Transparency refers to the right of an interested party to have access to public information as well as to the transparency as a general right (OECD, 2010). The first type of transparency refers to the right of a citizen participating in an administrative procedure to have access to documents on which a decision that might affect him/her is based. The second type of transparency refers to the general right of citizens to have access to all information officially held by public authorities.

Transparency of public institutions differs depending on the type of problems and the size of communities. According to Meijer (2009), transparency is high 
in traditional, smaller communities where people know each other and nobody could do things unnoticed. In larger cities where people do not know each other and social control is lower, direct transparency declines and it is replaced by modern, mediated transparency. Traditional or two-way transparency refers to the council meetings where citizens can see the councilors, hear the debates and make proposals, but also the councilors can see the citizens attending the meetings (Meijer, 2009; Hood, 2007). The modern, mediated transparency refers to the government transparency mediated by Internet, social media and other computerized systems; it is often one-way transparency because citizens have access to public information or watch council meetings, but councilors have no idea who is watching them or who is reading the information. Modern, mediated transparency is replacing traditional, direct transparency because face-to-face information and consultation become more difficult in large, dispersed towns that have variable problems. Cucciniello and Nasi (2014) distinguish between formal and useful transparency. Park and Blenkinsopp (2017) and Kovač (2016) highlight that public employees tend to stick rather with formal or technical view of transparency, while citizens have more practical concerns about the accessibility and utility of disclosed information.

A review of journal articles conducted by Cucciniello et al. (2017) that analyzed the benefits of transparency for citizens' participation in the decision making process highlights positive and consistent findings. The majority of the empirical studies examined suggest that greater transparency foster greater citizens' participation; however, some studies showed mixed and negative effects. The authors argue that the differences may be caused by the channels (or lack of them) used by citizens to engage with the government. In addition, other contextual factors, such as national cultural values, the form of government, the type of policy issue debated and policy domain, bear upon the effect of transparency (Cucciniello et al., 2017). Following the contextual view of transparency, Heimstädt and Dobusch (2018) analyzed transparency as an interorganizational process, and showed that different stakeholders advocated for forms of transparency that reflected the dominant logics and values of their professional fields. Similarly, Ben-Aaron et al. (2017) highlighted that public institutions do not act individually and do not diligently apply the laws, but rather they perform within an institutional context. The authors showed that the knowledge about peers' fulfillment behavior influenced the average time response to information request, and therefore seeing that their peers have already complied had subconscious, psychological effects that increased compliance with transparency requirements.

When public institutions increase organizational transparency by disclosing more information, they aim to increase citizens' knowledge about their activity and to encourage citizens' participation in the decision making process. Several studies showed that citizens do not base their judgment only on knowledge, but on emotions related to the activity of public institutions and the degree of understanding of the information disclosed. Grimmelikhuijsen (2012) found that the general trust in government explained a large proportion of a specif- 
ic trust in a public institution, and that citizens' general attitude toward government was more important than the effect of increasing transparency of a public institution. Porumbescu (2017) found that people who voiced more their opinions to the government were those who were not satisfied with the public services, and therefore read public institutions' websites and looked for information that documented their accusations of government mismanagement. According to the same author, improving transparency through the use of social media is effective at enhancing citizens' perceptions of government because the information presented is more general, and therefore easier to understand. Porumbescu (2017) recommends the use of different forms of transparency to target different objectives when aiming to improve the relationship with citizens. Pietrowski and Ryzin (2007) found that citizens who viewed government as closed demanded more transparency, whereas those who saw government closed sought less transparency. In addition, the research found the more confidence citizens had in their local officials, the less they were interested in fiscal and good government transparency.

Porumbescu et al. (2017) showed that the way in which the information is presented facilitates greater understanding of public institutions, and therefore the intention to comply. They also found that policy domain influences the degree of understanding of the information. Therefore, transparency is not a universal instrument to bolstering citizens' knowledge and compliance.

Internet and computer-based technology facilitate government transparency and diversify the ways in which public institutions provide citizens with opportunities to participate in the decision making process. Participation of the citizens is influenced by the government responsiveness and quality of response, which motivates citizens to participate frequently (Kim and Lee, 2012). In addition, the involvement of citizens should go further than voicing ideas and recommendations to truly empowering citizens to solve community problems, otherwise participation remains just a window-dressing ritual (Arnstein, 1969).

The current article aims to explore whether providing more information about the decision making process will encourage citizens to get more involved when public institutions make decisions.

\section{Short overview of Romanian decisional transparency law}

In 2003, the law no. 52/2003 on decisional transparency was adopted, and it sets the minimum procedural rules to guarantee decisional transparency of central and local public institutions. It is a piece of legislation that is distinct from Freedom of Information Act that regulates the disclosure of information of public interest by public authorities. However, the law no. 52/2003 includes also some legal provisions regarding the disclosure of draft normative acts before being proposed for adoption by a public institution. According to the law, its objective is to increase the accountability of public institutions and to stimulate the active participation of citizens in the decision-making process. 
The law establishes the procedural rules for ensuring the transparency of the decision making process. All public institutions from central and local level, and the institutions that use public funds are bound by law to publicize drafts of normative acts, to allow citizens and nongovernmental organizations to make recommendations on draft proposals, and to participate to deliberative meetings of the legislative bodies. According to article 3 of the law, the normative act is the act issued or adopted by a public authority, and which has a general applicability. It is an act that regulates general rules of behavior that should be applied repeatedly on an indefinite number of subjects. In 2016, Ministry for Public Consultation and Civic Dialogue and Ministry of Regional Development and Public Administration recommended some general guidelines to public institutions for identifying the draft decisions that should be subject to the transparency procedures: a) decisions that prescribe or sanction behaviors, b) decisions that involve allocation/reallocation of public resources: spending of public funds, renting/concession of buildings or lands, participation of a public institution to a national or international project as partner or applicant, c) decisions that aim to establish norms or standards for a particular group of the population, and the way the access to public resources will be granted, and d) decisions that are going to have an impact on a part or the entire population (Ministry for Public Consultation and Civic Dialogue and Ministry of Regional Development and Public Administration, 2016). Strategies and urban plans should also be subject to transparency procedures.

Provisions of the law do not apply to the normative acts on subjects related to national defense, national security and public order, the country's economic and political strategic interests, technical and economic data if their publication violates the principle of fair competition, and personal data. In addition, the administrative acts with an individual character are exempted from the transparency procedure.

According to the law, a public institution has to publicly announce the drafts of the normative acts 30 days in advance of being proposed for adoption, by posting them on the public institution website, at the public institution headquarter and to submit them to local or central mass-media. The public institution should submit the draft normative acts to all citizens who have submitted a request for receiving this information. The announcement regarding the drafting of a normative act should include: the date of display, a note of substantiation, a statement of reasons, an approval report on the need to adopt the proposed normative act, an impact or feasibility study, the full text of draft normative act, the deadline, the place and the way in which interested parties can submit in writing recommendations regarding the normative act. Public institutions should set a period of at least 10 calendar days in order to receive in writing recommendations or opinions on the draft normative acts subject to public debate. A public institution is required to organize a public consultation meeting to discuss a draft normative act, if this has been requested in writing by a legally established association or by another public authority.

Public institutions should announce the deliberative meetings of the legislative bodies 3 days in advance of the event. The announcement regarding the 
public meeting should be displayed at the public institution headquarter, on its website and sent to mass-media. Public institutions should announce the meeting to the citizens and the legally established associations that have submitted recommendations in writing. The announcement should contain the date, time and venue of the public meeting, as well as the agenda. Citizens are allowed to participate to deliberative public meetings and to make recommendations; however, their participation is made within the limits of the seats available in the room. After each meeting, the public institution should write a minute of the meeting containing information about how participants voted, and display it at headquarter of the institution and post it on its website. Public institutions are required to notify in writing the citizens and legally established associations that made recommendations about the motive for not including their recommendations in the final decision.

Any person who considers that his/her rights provided by the decisional transparency law have been broken has the right to file a complaint with the administrative court. The normative acts, which were not subject to the transparency procedure can be declared null. However, in case of a situation which, due to its exceptional circumstances, requires the adoption of immediate solutions, in order to avoid a serious prejudice to the public interest, the draft normative acts are subject to adoption under the emergency procedure (meaning without citizens' consultation).

\section{Methodology}

The goal of the research is to analyze whether decision making transparency contributes towards more citizens' and nongovernmental organizations' involvement in the decision making process. On the one hand, the research aims to analyze whether public institutions provide information about the decisions that are about to be made and provide interested parties with opportunities to participate in the decision making process. On the other hand, we aimed to find whether citizens and nongovernmental organizations get involved in the formal process of decision making by formulating recommendations and participating to council meetings. We conducted the analysis on the cities county residence because the issues that are solved at local level are closest to the needs and problems of the citizens, which incentivize them to get more involved in the decision making process, and we expected to find an increased number of citizens getting involved in the decision making process.

The research consists in a quantitative analysis of the annual reports that the public institutions have to compile regarding the application of the transparency law. We conducted the analysis for all 41 cities county residence from Romania and the six sectors in which Bucharest municipality is divided. We analyzed the annual reports for the years 2014, 2015, 2016 and 2017. In the first phase, we analyzed the webpages of all 47 institutions and in the case we did not find the annual reports, we emailed the person responsible for public relations asking for the missing reports. We included in the sample only those institutions for which we had the reports for all four years. However, we 
excluded from the sample those cities for which we had all the reports, but some important information was missing; therefore data was not comparable over time. The final sample on which we conducted the analysis consists of 33 administrative units: 28 cities county residence and 5 sectors of Bucharest municipality. The sample represents $70 \%$ of all the institutions considered for analysis. The Annex 1 includes the full list of the administrative units included the sample.

According to the transparency law, public institutions are required to publicize annually a report regarding the application of the law. The report should contain information regarding the number of normative acts adopted by public institutions, the number of administrative acts announced publicly, the channels used to publicize the normative acts, number of requests received for providing information on draft normative acts, number of recommendations received, and total number of recommendations included in draft normative acts. In addition, public institutions should disclose information about the decision making process by publicizing information about the number of local council meetings, the channels used to announce them, number of people who participated, total number of observations and recommendations expressed during these meetings, and total number of recommendations included in the decisions adopted. Public institutions should report the number of cases when an action in the administrative court was started against them for failing to comply with the provisions of the law.

We compared the findings of the current research with the results of other studies conducted by nongovernmental organizations regarding the application of the decisional transparency law. We aimed to identify whether we obtained similar results, and to collect further information about the implementation of the law. A second argument was that nongovernmental organizations in Romania played an important role on overseeing how public institutions implemented the transparency law. They acted as watchdogs, and their constant monitoring exposed those institutions which did not diligently apply the law.

\section{Results}

The quantitative analysis of the transparency reports show an increase in the number of normative acts adopted by City Halls from 6,628 in 2014 to 9,271 in 2017, which indicates a more active decision making activity of the public institutions. The largest majority of the normative acts were announced publicly, and their proportion fluctuated over time, such as between $97 \%$ (in 2016) to $83 \%$ (in 2017) (see Table 1). The fluctuation is caused by the type of proposals City Halls reported as normative acts, because a fewer percentage of total proposals are normative acts and have to be announced publicly and to be subject to public consultation ${ }^{1}$. In addition, when centralizing the data we observed that City Halls reported differently the number of normative

1 A part of the proposals subject to voting in the Local Councils are individual administrative acts, which are not required by law to be subject to public consultation. 
acts adopted. Some of them reported high numbers, while others reported significantly lower numbers. For example, in 2017 Cluj-Napoca City Hall reported 1,086 normative acts adopted, while Craiova City Hall reported only 11 (while the cities are of similar size). The difference is caused by how City Halls reported the proposals, one city reported all proposals subject to decision in Local Council, while the second city reported only the normative acts. Even though there are differences between what City Halls reported to be a normative act, we checked that each City Hall to keep the same classification over the analyzed period, therefore the trend identified when comparing the data over time to be reliable.

Table 1: Number of normative acts adopted and announced publicly, and the channels for announcing them

\begin{tabular}{|c|c|c|c|c|}
\hline & 2014 & 2015 & 2016 & 2017 \\
\hline No. of normative acts adopted & 6,628 & 6,690 & 5,995 & 9,271 \\
\hline $\begin{array}{l}\text { No. of normative acts } \\
\text { announced publicly } \\
\text { (Percentage of normative acts } \\
\text { announced publicly) }\end{array}$ & $\begin{array}{l}6,206 \\
(94 \%)\end{array}$ & $\begin{array}{l}5,751 \\
(86 \%)\end{array}$ & $\begin{array}{l}5,803 \\
(97 \%)\end{array}$ & $\begin{array}{l}7,711 \\
(83 \%)\end{array}$ \\
\hline \multicolumn{5}{|l|}{$\begin{array}{l}\text { Channels for announcing } \\
\text { normative acts }\end{array}$} \\
\hline $\begin{array}{l}\text { Website } \\
\text { (Percentage out of total no. } \\
\text { of normative acts announced } \\
\text { publicly) }\end{array}$ & $\begin{array}{l}5,350 \\
(86 \%)\end{array}$ & $\begin{array}{l}5,631 \\
(98 \%)\end{array}$ & $\begin{array}{l}5,517 \\
(95 \%)\end{array}$ & $\begin{array}{l}7,400 \\
(96 \%)\end{array}$ \\
\hline $\begin{array}{l}\text { Headquarter of public } \\
\text { institution } \\
\text { (Percentage out of total no. } \\
\text { of normative acts announced } \\
\text { publicly) }\end{array}$ & $\begin{array}{l}3,362 \\
(54 \%)\end{array}$ & $\begin{array}{l}2,711 \\
(47 \%)\end{array}$ & $\begin{array}{l}2,705 \\
(47 \%)\end{array}$ & $\begin{array}{l}3,904 \\
(51 \%)\end{array}$ \\
\hline $\begin{array}{l}\text { Mass-media } \\
\text { (Percentage out of total no. } \\
\text { of normative acts announced } \\
\text { publicly) }\end{array}$ & $\begin{array}{l}2,579 \\
(42 \%)\end{array}$ & $\begin{array}{l}2,356 \\
(41 \%)\end{array}$ & $\begin{array}{l}1,980 \\
(34 \%)\end{array}$ & $\begin{array}{l}3,057 \\
(40 \%)\end{array}$ \\
\hline
\end{tabular}

The main venue for announcing normative acts are websites of public institutions. In 2015, 2016 and 2017 more than 90\% of the normative acts were announced through this channel. Publication at headquarter of the public institution or in mass-media are of moderate use. The majority of City Halls used at least two methods for announcing the draft normative acts. 
The law grants citizens and business associations or other legally established associations the right to request information regarding drafts of normative acts. Between 2014 and 2017 the number of requests declined from 158 to 85 for all City Halls analyzed (Table 2), which might be caused by the large proportion of draft normative acts publicized by the public institutions.

Table 2: Number of requests for providing information on draft normative acts

\section{7}

No. of requests received for providing information on draft normative acts, from:

$\begin{array}{llll}158 & 82 & 42 & 85\end{array}$

Citizens

$\begin{array}{llll}104 & 53 & 25 & 55\end{array}$

Business associations or other legally established associations

$\begin{array}{llll}54 & 29 & 17 & 30\end{array}$

The number of recommendations received by public institutions increased from 348 in 2014 to 2,049 in 2017 (Table 3). Even though the increase seems to be large over the analyzed period, the total number of recommendations is not very large reported to the total number of normative acts publicized by City Halls. In 2014 only 14 out of 33 City Halls analyzed received at least one recommendation, while in 2017 their number increased to 26. The comparison of total number of suggestions received between 2014 and 2017 shows that General City Hall of Bucharest received the largest number $(1,636)$, followed by Cluj-Napoca City Hall (616), Iași City Hall (467) and Arad City Hall (335). These are cities with the largest population and the capital of Romania.

Table 3: Degree of public involvement in drafting normative acts

\begin{tabular}{|c|c|c|c|c|}
\hline & 2014 & 2015 & 2016 & 2017 \\
\hline Total no. of recommendations received & 348 & 575 & 1,446 & 2,049 \\
\hline $\begin{array}{l}\text { No. of City Halls that received } \\
\text { recommendations }\end{array}$ & 14 & 18 & 25 & 26 \\
\hline $\begin{array}{l}\text { Total no. of recommendations included in } \\
\text { draft normative acts }\end{array}$ & $\begin{array}{c}75 \\
(22 \%)\end{array}$ & $\begin{array}{c}123 \\
(21 \%)\end{array}$ & $\begin{array}{c}368 \\
(26 \%)\end{array}$ & $\begin{array}{c}567 \\
(28 \%)\end{array}$ \\
\hline $\begin{array}{l}\text { No. of public consultations organized } \\
\text { at the request of legally established } \\
\text { associations }\end{array}$ & 18 & 25 & 17 & 24 \\
\hline $\begin{array}{l}\text { No. of municipalities which had a least one } \\
\text { request to organize at least one public } \\
\text { consultation }\end{array}$ & 7 & 8 & 9 & 11 \\
\hline
\end{tabular}


A small number of observations were included in the final draft of normative acts (Table 3). In 2014, $22 \%$ of recommendations were included in the final drafts and the percentage improved just slightly by 2017 when it reached $28 \%$. The number of requests to organize public consultations coming from legally established associations remained small over the analyzed period, the highest number being of 25 meetings organized in 2015. However, the number of public institutions which had at least one request to organize a public consultation is very small. In 2014 only 7 out of 33 City Halls received at least one request, while in 201711 City Halls received such a request. The finding highlights the low level of interest of both citizens and nongovernmental organizations to demand public consultations. Still, the data does not portrait the entire picture regarding the organization of public hearings, because City Halls can organize public consultations at their own initiative.

The number of Local Council meetings increased from 688 in 2014 to 811 in 2017 (Table 4). More than 95\% of the meetings were announced on the public institutions' websites. The majority of public institutions used at least two channels to announce the council meetings. The estimated number of people who participated at Local Council meetings increased in 2015 comparatively with 2014, and in 2016 and 2017 it remained at almost the same level. Total number of recommendations voiced by citizens during Local Council meetings is overall small (Table 4), and it increased during the analyzed period from 397 in 2014 to 700 in 2017. The number of recommendations included in the final decisions increased from 195 in 2014 to 324 in 2017. In average, half of the recommendations were included in final decisions. The proportion is higher than the percentage of suggestions included in the drafts of normative acts during the consultation procedure, which was approximately 28\% in 2017.

Table 4: Citizens' participation in the deliberative process

\begin{tabular}{|c|c|c|c|c|}
\hline & 2014 & 2015 & 2016 & 2017 \\
\hline No. of Local Council meetings & 688 & 767 & 743 & 811 \\
\hline \multicolumn{5}{|l|}{ Channels for announcing council meetings } \\
\hline a. headquarter of public institution & $\begin{array}{l}533 \\
(77 \%)\end{array}$ & $\begin{array}{l}581 \\
(76 \%)\end{array}$ & $\begin{array}{l}562 \\
(76 \%)\end{array}$ & $\begin{array}{l}680 \\
(84 \%)\end{array}$ \\
\hline b. website & $\begin{array}{c}661 \\
(96 \%)\end{array}$ & $\begin{array}{c}741 \\
(97 \%)\end{array}$ & $\begin{array}{l}725 \\
(98 \%)\end{array}$ & $\begin{array}{l}770 \\
(95 \%)\end{array}$ \\
\hline c. mass-media & $\begin{array}{c}591 \\
(86 \%)\end{array}$ & $\begin{array}{c}612 \\
(80 \%)\end{array}$ & $\begin{array}{l}555 \\
(75 \%)\end{array}$ & $\begin{array}{c}579 \\
(71 \%)\end{array}$ \\
\hline $\begin{array}{l}\text { Estimated no. of people who participated } \\
\text { to council meetings }\end{array}$ & 12,451 & 15,481 & 14,635 & 14,591 \\
\hline $\begin{array}{l}\text { No. of recommendations voiced during } \\
\text { council meetings }\end{array}$ & 397 & 304 & 369 & 700 \\
\hline $\begin{array}{l}\text { No. of recommendations included in the } \\
\text { final decisions }\end{array}$ & $\begin{array}{c}195 \\
(49 \%)\end{array}$ & $\begin{array}{c}118 \\
(39 \%)\end{array}$ & $\begin{array}{l}205 \\
(56 \%)\end{array}$ & $\begin{array}{l}324 \\
(46 \%)\end{array}$ \\
\hline
\end{tabular}

122 Central European Public Administration Review, Vol. 17, No. 1/2019 
In very few cases public institutions reported that a complaint was filled with an administrative court for breaking the transparency procedures. In most of the cases, institutions reported that the actions in court were still pending (18 cases), in 2 cases the courts decided in favor of the plaintiffs, and 3 cases in favor of the public institutions.

In the following section we will discuss the findings of the research, will compare the findings with the results of similar studies, and we will analyze the limits of our research.

\section{Discussion}

The quantitative analysis of the annual transparency reports highlights an overall low level of citizens' participation in the decision making process. Even though the number of recommendations made during the consultation and deliberation stages of the decision making process increased between 2014 and 2017, it is still small comparatively with the number of draft normative acts proposed for adoption. The majority of analyzed public institutions reported that they did not receive any recommendations. The larger cities received the highest number of suggestions, which can be influenced by the larger number of normative acts subject for adoption and larger population. Public institutions reported few public consultations organized upon the request of citizens and nongovernmental organizations. The low number of complaints with the administrative courts indicate the low level of awareness among citizens that Local Council decisions, which did not follow the transparency procedures, might be declared null by the administrative courts.

In the following part we will compare the findings of our research with the results of researches conducted previously by some nongovernmental organizations. As we mentioned earlier in the article, nongovernmental organizations were instrumental in putting pressure on public institutions to diligently implement the decisional transparency law and freedom of information act.

A research conducted by Coalition 52, Advocacy Coalition and Foundation for Civil Society Development (2015) reached the same conclusion. Only 2\% out of 846 public authorities questioned reported that they organized a public consultation upon request, and $22 \%$ organized a consultation upon their own initiative between February and October 2015. Institute for Public Policies (2013) conducted a research regarding the implementation of the decisional transparency law between 2009 and 2011 by sending questionnaires to a sample of 119 public institutions from local and central level, and 150 nongovernmental organizations. The results showed that the organization of public consultations was a formal procedure, and rather an obstacle for public institutions when making decisions. Public institutions were reluctant to organize public consultations because the procedure made the decision making process more difficult. A possible cause is that citizens do not have the knowledge or the expertise to understand the draft normative acts (Vrabie et al., 2014). 
The analysis conducted by Romanian Academic Society (2015) on transparency reports of 106 public authorities for the years 2013 and 2014 showed that citizens tend to participate more in the consultation stage of the decision making process rather than in the deliberation stage. The authors argued that citizens perceived that their recommendations had higher chances to modify the draft normative acts than during a deliberation meeting with long agenda and tight schedule of voting the legislative proposals. This finding is in contradiction with the results of our research, which might be caused by the difference between the samples we used.

The low level of trust in public institutions in Romania might explain the low level of citizens' participation in the decision making process, because "people abstain from engaging in civic activities ... when they are skeptical about the impact that their acts might have" (Bădescu, Sum and Uslaner, 2004, p. 325). In the past years, several opinion polls showed a low level of trust in local public administration, the mayor, public employees and local councilors in Romania. In 2016 Romanian Institute for Evaluation and Strategy conducted an opinion poll on a representative sample at national level of 900 people, and found that $25 \%$ of the respondents trusted much and very much the mayor, $17 \%$ of people trusted local councilors and $29 \%$ of them trusted civil servants (Romanian Institute for Evaluation and Strategy, 2016). The results showed a decreasing trend in citizens' trust in local public administration comparatively with a research conducted by the same research institute in 2015 (Romanian Institute for Evaluation and Strategy, 2015). Institute collected the information through telephone survey. In 2016, INSCOP Research found that $37.3 \%$ of the respondents trusted the City Hall; data was collected through a questionnaire applied at the respondent's residency.

The use of Internet might help citizens to have easier access to information about the draft normative acts subject to adoption. However, Eurostat data shows that the percentage of people that use Internet frequently in Romania is low comparatively with other European Union member states (61\% in 2017), while only $3 \%$ of them use Internet to take part in on-line consultations or voting to define civic and political issues, and $8 \%$ use Internet for civic and political participation.

The low level of citizens' involvement in the decision making process is also rooted in a poorly developed participatory culture of the Romanian public administration. During communist regime, public institutions discouraged any type of opposition to public decisions, and public consultations and voting process were manipulated by communist elite toward the desired outcomes. Citizens were expected to diligently bind the rules, and not to be involved in initiating or designing them. Any opinion in opposition with the communist propaganda was discouraged or punished. After the fall of the communist regime, building a more open and transparent public administration was a gradual process, and the efforts toward fostering citizen participation and building community capacity to solve problems remained marginal. Based on a survey conducted on a representative sample at national level of top level civil ser- 
vants and public officials, Haruța and Radu (2010) found that the information provided by citizens is of moderate importance for public officials when making decisions, as the most important elements are legal framework, budgetary constraints and the conclusions of reports, statistics and different analyses. The findings of the current research are consistent with other previous academic research, which indicates a low level of citizens' participation in the decision making process in Romania (Haruța and Radu, 2010), an insufficient implementation and use of decisional transparency law (Schnell, 2018), indifference and sometimes fear of citizens from rural communities to participate (Pascaru and Buțiu, 2010), and that public institutions comply only formally with the provisions of the decisional transparency law (Dragoș et al., 2012).

The study we have conducted has several limitations. The methodology used to collect the information allowed us to draw limited conclusions with regard to the implementation of the law and the citizens' participation in the decision making process. Other research methods would allow to collect in depth information, such as interviews with the civil servants responsible with the application of law or direct observation of local council meetings. In addition, we have some doubts regarding the accuracy of the data reported by public institutions. We observed that City Halls reported differently normative acts; some City Halls reported all decisions adopted by Local Councils, while others reported only those proposals that were considered normative acts according to the transparency law. Even though there is a recommended table format for reporting the information, some City Halls wrote narrative reports instead of filling the table, and the narrative reports did not contain all the recommended information, which determined us to exclude them from the sample.

Even though the picture portrayed by our research is of low level of citizens' participation, the transparency reports did not count for other forms of citizens' involvement in the decision making process that City Halls have developed over the past years. For example, Cluj-Napoca City Hall implemented for the first time participatory budgeting in 2013, and by 2018 Timișoara, Oradea and Sibiu City Halls and City Hall of Sector 1 Bucharest embraced the initiative. Through this program citizens can propose and decide on the most pressing problems of the city for which a part of the local budget to be spent. Internet based technology facilitated alternative opportunities for citizens' participation. For example, Cluj-Napoca City Hall has developed an online platform (MyCluj), through which residents can signal problems on ongoing basis or even suggest alternative solutions for solving existing problems, while the municipality informs them on the problem solving status. The application process for different designations that cities compete for, such as European Capital of Culture and European Capital of Youth, requires that the proposals to be the outcome of a participatory process of relevant stakeholders from the community, and to represent a shared vision for the city. The process of drafting these applications empowers citizens to get involved in the decision making process, as well as in the implementation stage in case a city receives the designation. These examples illustrate that the citizens' participation in different stages of the decision making process at municipal level in Romania has em- 
braced more diverse forms. Transparency is an important prerequisite for citizens' participation, but citizens' involvement can be encouraged through multiple mechanisms that are more adapted to new information technologies.

\section{Conclusions}

The decisional transparency law created the legal framework to make the activity of public institutions more transparent and to give citizens' the opportunity to get involved in the decision making process. Even though great improvements have been achieved, the level of citizens' participation in formal procedures of legislative process at local level is low. Public institutions tend to technically apply the provisions of the law and to concentrate less on organizing meaningful consultations for collecting a diversity of opinions. Without a true citizens' empowerment the requirements on public institutions to become more transparent remain a window-dressing ritual (Arnstein, 1969). 


\section{References}

Arnstein, S. (1969). A Ladder of Citizen Participation. Journal of the American Planning Association, 35(4), pp. 216-224.

Asllani, D. (2016). The Information and Data Protection Commissioner's Effectiveness on Transparency. The NISPAcee Journal of Public Administration, 9(2), pp. 11-27.

Bădescu, G., Sum, P. and Uslaner, E. (2004). Civil Society Development and Democratic Values in Romania and Moldova. East European Politics and Societies, 18(2), pp. 316-341.

Coalition 52, Advocacy Coalition and Foundation for Civil Society Development (2015). Consultarea Publică sub Lupă! Rezultatele cercetării 'M-am decis să mă implic' (Public Consultation under Magnifying Glass! Results of the Research "I Decided to Get Involved"). At <https://comunitateadeadvocacy. wordpress.com/2015/12/09/conferinta-de-presa-consultarea-publicasub-lupa-rezultatele-cercetarii-m-am-decis-sa-ma-implic-romania-2015/>, accessed 28 July 2018.

Cucciniello, M. and Nasi, G. (2014). Transparency for Trust in Government: How Effective is Formal Transparency? International Journal of Public Administration, 37(13), pp. 911-921.

Cucciniello, M., Porumbescu, G. and Grimmelikhuijsen, S. (2017). 25 Years of Transparency Research: Evidence and Future Directions. Public Administration Review, 77(1), pp. 32-44.

Curtin, D. and Meijer, A. (2006). Does Transparency Strengthen Legitimacy? A Critical Analysis of European Union Policy Documents. Information Polity, 11, pp. 109-122.

Dragoș, D. (2006). Transparency in Public Administration: Free Access to Public Information. A Topical Comparative Analysis of Several Jurisdictions from Central and Eastern Europe. Transylvanian Review of Administrative Sciences, 17E, pp. 26-42.

Dragoș, D., Neamțu, B. and Cobârzan, B. (2012). Procedural Transparency in Rural Romania: Linking Implementation with Administrative Capacity. International Review of Administrative Sciences, 78(1), pp. 134-157.

Eurostat Database. At <https://ec.europa.eu/eurostat/data/database>, accessed 2 August 2018.

Garrido-Rodriguez, J., Zafra-Gómez, J. and López-Hernández, A. (2017). Measuring Local Government Transparency. Influence of Political Sign in Multidimensional Analysis. Lex-Localis - Journal of Local Self-Government, 15(4), pp. 889-917.

Grimmelikhuijsen, S. (2009). Do Transparent Government Agencies Strengthen Trust? Information Polity, 14, pp. 173-186.

Grimmelikhuijsen, S. (2012). Link Transparency, Knowledge and Citizen Trust in Government: An Experiment. International Review of Administrative Sciences, 78(1), pp. 50-73.

Haruța, C. and Radu, B. (2010). Citizen Participation in the Decision Making Process at Local and County Level in the Romanian Public Institutions. Transylvanian Review of Administrative Sciences, 31E, pp. 76-92.

Heimstädt, M. and Dobusch, L. (2018). Politics of Disclosure: Organizational Transparency as Multiactor Negotiation. Public Administration Review, 78(5), pp. 727-738. 
Hințea, C. and Țiclău, T. (2017). Public Administration Reform in Romania after 25 Years. In P. Kovač and M. Bileišis, eds., Public Administration Reforms in Eastern European Union Member States. Ljubljana, Vilnius: Faculty of Administration of University of Ljubljana, Mykolas Romeris University Lithuania, pp. 389-426.

Hood, C. (2007). What Happens When Transparency Meets Blame Avoidance? Public Management Review, 9(2), pp. 191-210.

INSCOP Research (2016). Barometrul. Adevărul despre România (Barometer. Truth about Romania). At <https://www.inscop.ro/wp-content/ uploads/2016/04/INSCOP-raport-martie-2016-INCREDERE-INSTITUTII.pdf>, accessed 5 September 2018.

Institute for Public Policies (2013). Condițiile și provocările procesului de adoptare a politicilor publice din România - politica de comunicare publică (Conditions and Challenges of the Public Policies Decision Making in Romania - Public Communication Policy), Bucharest. At <http://dialogsocial.gov.ro/ wp-content/uploads/2016/03/ipp-studiu-comunicare-publica.pdf>, accessed 25 June 2018.

Kim, S. and Lee, J. (2012). E-participation, Transparency, and Trust in Local Government. Public Administration Review, 72(6), pp. 819-828.

Kovač, P. (2016). Openness and Transparency in (Slovene) Administrative Procedures as Fundamental European Principles. The NISPAcee Journal of Public Administration, 9(2), pp. 49-67.

Law no. 52/2003 regarding decisional transparency in public administration, republished in Official Monitor of Romania no. 749 from 3 December 2013.

Lee, G. and Kwak, Y. (2012). An Open Government Maturity Model for Social Media-Based Public Engagement. Government Information Quarterly, 29, pp. 492-503.

Meijer, A. (2009). Understanding Modern Transparency. International Review of Administrative Sciences, 75(2), pp. 255-269.

Meijer, A. (2013). Understanding the Complex Dynamics of Transparency. Public Administration Review, 73(3), pp. 429-439.

Ministry for Public Consultation and Civic Dialogue and Ministry of Regional Development and Public Administration (2016). Consultarea publică eficientă la nivelul administrației centrale și locale. Ghid practic pentru aplicarea Legii nr. 52/2003 privind transparența decizională în administrația publică (Efficient Public Consultation at the Level of Central and Local Public Administration. Practical Guide for the implementation of Law nr. 52/2003 regarding decisional transparency in public administration), Bucharest. At <http://dialogsocial.gov.ro/wp-content/uploads/2016/07/Ghid-52-final_culink-uri.pdf>, accessed 25 June 2018.

OECD (2010). The Right to Open Public Administration in Europe: Emerging Legal Standards, SIGMA Paper no. 46. At <http://www.epsa2011.eu/files/ Themes_2011/OECD\%20Administrative\%20Transparency\%201010.pdf>, accesse 20 March 2018.

Park, H. and Blenkinsopp, J. (2017). Transparency Is in the Eye of the Beholder: The Effect of Identity and Negative Perceptions on Ratings of Transparency via Surveys. International Review of Administrative Sciences, 83(1S), pp. 177-194.

Pascaru, M. and Buțiu, C. (2010). Psycho-Sociological Barriers to Citizen Participation in Local Governance. The Case of Some Rural Communities in Romania. Local Government Studies, 36(4), pp. 493-509. 
Pietrowski, S. and Van Ryzin, G. (2007). Citizen Attitudes toward Transparency in Local Government. Review of Public Administration, 37(3), pp. 306-323.

Porumbescu, G. (2017). Linking Transparency to Trust in Government and Voice. American Review of Public Administration, 47(5), pp. 520-537.

Porumbescu, G., Lindeman, M., Ceka, E. and Cucciniello, M. (2017). Can Transparency Foster More Understanding and Compliant Citizens? Public Administration Review, 77(6), pp. 840-850.

Prechal, S. and Leeuw, M. (2007). Dimensions of Transparency: The Building Blocks for a New Legal Principle? Review of European Administrative Law, $0(1)$, pp. 51-61.

Radu, B. and Dragoș, D. (2019). Freedom of Information in Romania - Legal and Empirical Insights. In D. Dragoș, P. Kovač, and A. Marseille, eds., The Laws of Transparency in Action: A European Perspective. Palgrave Macmillan, pp. 425-470.

Radu, L. (2015). How to Develop Sustainable Public Administration Reforms. Transylvanian Review of Administrative Sciences, 44E, pp. 180-195.

Romanian Academic Society (2015). Studiu - anchetă privind implementarea Legii 52/2003, modificată în 2013 - privind transparența decizională a autorităților public din România (Study regarding the implementation of the Law 52/2003, modified in 2013, regarding the decision making transparency of public authorities from Romania). At <http://www.romaniacurata.ro/ wp-content/uploads/2016/02/Studiu_SAR_AA_aplicare-L52-transparentadecizionala.pdf>, accessed 25 June $2 \overline{0} 18$.

Romanian Institute for Evaluation and Strategy (2015). România, Barometrul Încrederii. Administrația Locală (Romania. Barometer of Trust in Local Public Administration). At <http://www.ires.com.ro/uploads/articole/ires barometrul-increderii_adminiatratia-locala_martie-2014.pdf $>$, accessed 5 September 2018.

Romanian Institute for Evaluation and Strategy (2016). România - Societate cu Încredere Limitată (Romania - A Society with Limited Trust). At <http:// www.ires.com.ro/uploads/articole/ires_criza-de-incredere-perceptii-sireprezentari_sinteza_ianuarie-2016.pd $\bar{f}>$, accessed 5 September 2018.

Schnell, S. (2018). From Information to Predictability: Transparency on the Path to Democratic Governance. The Case of Romania. International Review of Administrative Sciences, 84(4), pp. 692-710.

Schnell, S. (2018). Cheap Talk or Incredible Commitment? (Mis)calculating Transparency and Anti-corruption. Governance, 31(3), pp. 415-430.

Vrabie, C., Dobre, S. and Zamfirescu, I. (2014). Cum se iau deciziile în Capitală? O analiză cantitativă și calitativă a deciziilor pregătite de Primăria Municipiului București și votate de Consiliul General al Municipiului București în perioada iulie-noiembrie 2014 (How Decisions Are Made in Capital City? A Quantitative and Qualitative Analysis of Decisions Drafted by Bucharest City Hall and Voted by General Council of Bucharest between July and November 2014). At <http://dialogsocial.gov.ro/wp-content/uploads/2016/03/raport_deciziiCapitala_final-v2.pdf>, accessed 20 June 2018. 


\section{Appendix:List of the administrative units included in the analysis}

\section{Type of administrative unit}

City Halls of cities county residence: Arad, Bacău, Baia Mare, Bistrița, Brașov, Buzău, Călărași, ClujNapoca, Constanța, Craiova, Deva, Galați, Giurgiu,

1 Oradea, Pitești, Ploiești, Râmnicu Vâlcea, Iași, SatuMare, Sfântu Gheorghe, Sibiu, Slatina, Slobozia, 28 (out of 41 ) Târgu Jiu, Târgu Mureș, Timișoara, Zalău, General City Hall of Bucharest

2 City Halls of Bucharest Sectors: Sector 1, 2, 3, 4 and 6

No. of cities

5 (out of 6) 